\title{
Inorganic Phosphorous, Lime and Vermicompost Induced Changes on Phosphorus Fractions and Other Properties of Acidic Soil of Cheha District, Ethiopia
}

Bereket Ayenew Alemu ( $\nabla$ bersofsam12@gmail.com)

Haramaya University College of Agricultural and Environmental Sciences

Asmare Melese

Debre Berhan University

\section{Research Article}

Keywords: oxyhydroxides, soil acidity, inorganic amendment, phosphorous fraction

Posted Date: March 16th, 2021

DOI: https://doi.org/10.21203/rs.3.rs-250222/v1

License: () (1) This work is licensed under a Creative Commons Attribution 4.0 International License. Read Full License 


\section{Abstract}

Background: In acid soils, soluble inorganic phosphorus is fixed by aluminum and iron, so that phosphorous availability to plant would be inhibited. Thus, an incubation study was conducted to evaluate the effects of lime, vermicompost, and mineral $P$ fertilizer on the distribution of $P$ fractions and oxalate and dithionite extractable aluminum and iron. The treatments consisted of three rates of phosphorous $\left(0,74.51\right.$ and $149.01 \mathrm{~kg} P$ ha $\left.{ }^{-1}\right)$, three rates of vermicompost $\left(0,5\right.$ and 10 ton $\left.\mathrm{VC} \mathrm{ha}{ }^{-1}\right)$ and four rates of lime $\left(0,5.70,9.20\right.$, and 11.50 ton $\left.\mathrm{CaCO}_{3} \mathrm{ha}^{-1}\right)$. The experiment was laid out as a complete randomized design in a factorial arrangement.

Results: Combined application of lime, vermicompost and mineral $P$ significantly increased $(p<0.05)$ labile phosphorus fractions and decreased potential sorption capacities of the soil. As the increased soil $\mathrm{pH}$, reduced exchangeable acidity and oxalate extractable Fe and Al the integrated applications of these amendments fixed aluminum and iron instead of phosphorus, thus rendering phosphorus available by keeping the inorganic phosphorus in a bioavailable labile phosphorus pool compared to sole application of the amendments.

Conclusions: Combined applications of lime, vermicompost and inorganic P to acidic soils of Goha-1 in Cheha district could convey enhanced amount of available $P$ and ensures the maintenance of higher levels of labile $P$. It might also contribute towards meeting crop $P$ requirements.

\section{Background}

Soil acidity is the most central factor affecting plant growth and limiting crop production (Van Straaten 2007; Fageria 2009; Achieng et al.2010). It is common in regions where rainfall is high enough to leach appreciable amounts of exchangeable bases from soil surface (Achalu et al.2012b). Soil acidification affected large areas of Ethiopian highlands estimated at $40 \%$ of the total arable land of the country (Mesfin 2007; Hirpa et al. 2013). Particularly, it becomes a serious threat to western and southern highlands of Ethiopia (Wassie and Boke 2009). Soil acidification arises from leaching of bases down the profile through the action of rainfall, continuous cropping, and crop removal of basic cations (Oluwatoyinboet et al. 2009). Consequently phosphorus is deficient in most acid soils because soluble inorganic $P$ is fixed by Al and Fe (Adnan et al. 2003). This reaction contributes to less availability of P for crops (Chandrasekaran et al. 2010).

In highly weathered acidic soils, Fe and Al oxyhydroxides are the dominant species with which P readily interacts (Tan 2000; Sims and Pierzynski 2005; Ahmed et al. 2008; Rayment and Lyons 2011). These oxyhydroxides create new functional groups for P adsorption (Roderigo et al. 2016) and may be found as distinct surface layers on soil particles or in complexes with the organic fraction of the soil (Sims and Pierzynski 2005). These short range crystalline oxyhydroxides (amorphous) are well known to affect P sorption in soils (Janardhanan and Daroub 2010).

In acid soils, high levels of exchangeable Al and Fe play a significant role in controlling orthophosphate concentration in the soil solution (lyamuremye and Dick 1996; Haynes and Mokolobate 2001; Erich et al. 2002). Therefore, crop production on these soils can be improved greatly by adjusting the pH to near neutrality (Whalen et al. 2000). The availability of $\mathrm{P}$ is influenced by soil organic matter, $\mathrm{pH}$, and exchangeable and soluble Al, Fe, and Ca (Smithson, 1999). Conventionally, large amounts of lime and inorganic $\mathrm{P}$ fertilizers are used to saturate Al and Fe ions. This approach alone has not been successful because it is not economical and not environmentally friendly (Ch'ng et al. 2014).

Soils contain inorganic $\mathrm{P}(\mathrm{Pi})$ and organic $\mathrm{P}(\mathrm{Po})$ compounds that are important $\mathrm{P}$ sources for plants, but Po rarely represents a major portion of soil $\mathrm{P}$. The inorganic $\mathrm{P}(\mathrm{Pi})$ compounds mainly couple with amorphous and crystalline forms of $\mathrm{Al}, \mathrm{Fe}$, and $\mathrm{Ca}$ (Negassa and Leinweber 2009). Information of $\mathrm{P}$ fraction dynamics in acidic soils is significant to evaluate $\mathrm{P}$ mobility in order to reduce the $\mathrm{P}$ retention by soils. In soils, $\mathrm{P}$ is found in several forms or pools, and different forms are often designated as either inorganic or organic P (Hedley et al. 1982; Reddy et al. 1998). These descriptions imply differences among P forms with respect to reactivity in the environment. Moreover, $P$ fertilization can result in changes in soil $P$ fractions which provide valuable facts on the impacts of $\mathrm{P}$ additions on soil $\mathrm{P}$ transformations (Zhang et al. 2006; Lan et al. 2012).

In natural or agricultural ecosystems having low $\mathrm{P}$ soils, mineralization of organic $\mathrm{P}$ is the main source of $\mathrm{P}$ supply to plants, especially in highly weathered tropical soils (Vincent et al. 2010). The contribution of soil organic P to increase available P (labile P) can be more relevant when organic fertilization or other practices which can increase the soil organic matter content (OM) are part of the soil management. Organic fertilization affects the $\mathrm{P}$ availability, Pi release (Hue et al., 1994) or microbial immobilization of soil Pi (Chen et al. 2000), competition between organic acid anions and phosphate anions for adsorption sites (Andrade et al. 2003; Guppy et al. 2005). Moreover, Pi compound dissolution by organic acids and metal complexation, particularly of $\mathrm{Al}^{3+}$ and Fe $\mathrm{F}^{2+}$ (Andrade et al. 2003), with lower phosphate anion precipitation reactions can occur because of organic fertilization.

The maintenance of adequate amounts of $\mathrm{P}$ in the soil and keeping the wellbeing of the soil through organic and inorganic fertilizer applications are critical for the long term sustainability of agricultural systems. Moreover, a clearer understanding of the change in distribution and solubility of $\mathrm{P}$ forms in soil may provide important information for the evaluation process of P availability for plants and to enhance the fertilizer management strategy (Sharply et al. 2004). For example, there is an increasing interest in the potential use of vermicompost (VC) as soil amendment (Lordan et al. 2013). Reshid (2016) noted that application of VC showed remarkable improvements in the soil physical and biochemical properties, which in turn enhance the availability of $\mathrm{P}$ to plants in acidic soils.

Low soil acidity, higher oxyhydroxides of $\mathrm{Al}$ and Fe content, low P concentrations in the soil solution and higher P adsorption capacity are the characteristic features of the studied soil (Ayenew et al. 2018b). The impact of integrated application of lime, vericompost and mineral P on the distribution of oxyhydroxides of Fe and $\mathrm{Al}$, organic $\mathrm{P}$, and inorganic $\mathrm{P}$ fractions have not yet been evaluated in the study area. Thus, for proper $\mathrm{P}$ fertilizer management and surmount the low plant availability of soil $\mathrm{P}$, the effects of applications of amendments on adsorption characteristics, $\mathrm{P}$ fractions dynamics and related properties are required to be tested. Moreover, in spite of the existing $\mathrm{P}$ fixation problem in highland soils of Ethiopia, little work has been done on dynamics of

Page 2/16 
$\mathrm{P}$ (inorganic and organic fractions) and related properties up on sole or combined applications of organic and inorganic amendments. Studies focusing merely on inorganic P forms have been conducted by Dawit et al. (2002); Wakene and Heluf (2003); Berhane and Sahlemedhin (2003); Shiferaw (2004); Achalu et al. (2014) and Asmare et al. (2015). However, since available P in soil is not a single entity, complete accounts of the P forms (organic and inorganic) present in the soils have to be appreciated in order to determine the fate of the applied P fertilizers (Dawit et al. 2002). Therefore the purpose of this study was to evaluate the effects of sole and combined applications of lime, VC and inorganic $\mathrm{P}$ on dynamics and distribution of different $\mathrm{P}$ fractions as well as related soil properties.

\section{Materials And Methods}

\section{Description of the study area}

The study was conducted in Cheha district of Gurage zone in south western Ethiopia. The district is situated between $8^{0} 32^{\prime} 0^{\prime \prime}$ and $8^{0} 20^{\prime} 0^{\prime \prime} \mathrm{N}$, and $37^{0} 41^{\prime} 20^{\prime \prime}$ and $38^{\circ} 2^{\prime} 40^{\prime \prime} \mathrm{E}$, at an elevation that ranges from 900 to 2812 masl. EIAR (2011) classified the area into three agro-ecological zones i.e. highlands (2300 3200 masl), midlands (1500 - 2300 masl), and lowlands (500 - 1500 masl) based on the bimodal rainfall system. The ten years mean annual rainfall of the district is about $1268 \mathrm{~mm}$. The mean annual maximum and minimum temperatures are 24.97 and $10.69^{\circ} \mathrm{C}$, respectively. The dominant soil types in the study area are: Nitisols, Leptisols, and Pellic Vertisols [FAO (Food and Agriculture Organization) 1988].

\section{Site selection, soil sampling and analysis}

A preliminary soil survey and field observation was made using topographic map $(1: 50,000)$ of the study area. Soil pH (potentiometer), altitude (GPS), and slope (clinometer) were used as criteria for selection of soil sampling sites. Fifteen (15) sub-samples were collected from Goha 1 (SC1) study site to make one composite sample. Accordingly, one composite soil sample $(0-15 \mathrm{~cm})$ having pH value of less than 5.5 was obtained within an altitudinal range of 2000 3000 masl and slope less than $8 \%$. Soil pH was measured at field condition using portable pH meter to select soils having a pH of less than 5.5 . The soil samples were put in plastic bag, tagged, and transported to laboratory for analysis. Consequently, about $1 \mathrm{~kg}$ of composited soil sample was air dried and ground to pass through a $2 \mathrm{~mm}$ sieve for analysis of selected soil properties except organic carbon ( $0.5 \mathrm{~mm}$ sieve) according to the standard methods.

\section{Soil P fractions and other related properties}

Different forms of $\mathrm{P}$ were determined following the $\mathrm{P}$ fractions scheme suggested by Hedley et al. (1982) as modified by Chen et al. (2000). The oxalate extractable $\mathrm{P}, \mathrm{Al}$ and $\mathrm{Fe}\left(\mathrm{P}_{\mathrm{ox}}, \mathrm{Al}_{\mathrm{ox}}\right.$ and $\mathrm{Fe}$ ox $)$ were determined with $0.05 \mathrm{M}$ ammonium oxalate $\left(\left(\mathrm{NH}_{4}\right)_{2} \mathrm{C}_{2} \mathrm{O}_{4} .2 \mathrm{H}_{2} \mathrm{O}\right.$, pH 3.3) in the dark (Mckeague and Day 1966). Citrate bicarbonate dithionite-extractable Fe and $\mathrm{Al}\left(\mathrm{Fe}_{\mathrm{d}}\right.$ and $\left.\mathrm{Al}_{\mathrm{d}}\right)$ were determined by the method of Mehra and Jackson (1960). The degree of $\mathrm{P}$ saturation (DPS) was determined as the percentage of the ratio of the different forms of $\mathrm{P}$ to the oxalate extractable $\mathrm{Al}$ and $\mathrm{Fe}\left(\mathrm{Al}_{\mathrm{ox}}\right.$ and $\mathrm{Fe} \mathrm{ox}_{\mathrm{ox}}$ ( $\mathrm{Van}$ der $\mathrm{Zee}$ et al., 1988). The $\mathrm{P}$ adsorption capacity (PSC, $\mathrm{mmol} \mathrm{kg}^{-1}$ ) of the soil was calculated and estimated according to Börling et al. (2001).

\section{Analysis of the composition of vermicompost and lime}

Parthenium hysterophorus, wheat straw, cow dung and poultry manure, were used as substrates in preparing the vermicompost. Consequently the $\mathrm{pH}, \mathrm{OC}, \mathrm{C}: \mathrm{N}$, and total concentrations of nitrogen $(\mathrm{N})$, phosphorous $(\mathrm{P})$, potassium $(\mathrm{K})$, calcium $(\mathrm{Ca})$, magnesium $(\mathrm{Mg})$, and sodium (Na) in the vermicompost were determined. The total nutrient contents of vermicompost were measured in suspensions obtained after dry ashing at $500^{\circ} \mathrm{C}$, followed by cooling to room temperature in muffle furnace, slowly removal of ashed samples and dissolving with $1 \mathrm{~N} \mathrm{HCl}$ and diluted to 50 ml volume. Each element was analyzed based on standard laboratory procedure suggested by Gavlak et al. (2005). Phosphorous was determined by the Vanado-molybdate colorometric procedure using spectrophotometer at $460 \rrbracket \mathrm{m}$ wavelength. Calcium and $\mathrm{Mg}$ were determined by FAAS, as $\mathrm{Na}$, and $\mathrm{K}$ were determined with flame photometer. The total $\mathrm{N}$ contents of the vermicompost samples were determined by the micro-Kjeldhal method as described by Gavlak et al. (2005). Organic matter was determined by the dichromate oxidation method of Walkley and Black (1934). Vermicompost pH values was measured in water (sample: water ratio of 1:5) using a pH meter. The calcium carbonate equivalents (CCE) of the lime was determined by dissolving the lime using excess of standard $0.5 \mathrm{M} \mathrm{HCl}$ and followed by gentle boiling. After filtration, the excess $\mathrm{HCl}$ was back titrated with standard $0.1 \mathrm{M} \mathrm{NaOH}$ solution using phenolphthalein as an indicator. From the amount of $\mathrm{NaOH}$ used to neutralize the excess acid of the blank and the filtrate, the CCE values of the lime were calculated.

\section{Incubation experiment}

The composited soil sample $(0-15 \mathrm{~cm})$ was air dried, ground and passed through $2 \mathrm{~mm}$ sieve and then $300 \mathrm{~g}$ soil was placed in plastic pot in the green house for the next step. Three rates of lime were decided of which two of them 9.20 , and 11.50 tons $\mathrm{CaCO}_{3} \mathrm{ha}^{-1}$ were separately applied to obtain target $\mathrm{pH}$ values of 6.0, 6.5 and the third one was 5.70 tons $\mathrm{CaCO}_{3} \mathrm{ha}^{-1}$ which is half of the lime required to bring a pH value of 6.5 for soil from Goha 1 (SC1) sampling site. The lime used for this particular study had a CCE of $96.15 \%$. Hence, the actual field application rates of lime were $0,5.93,9.57$, and 11.96 tons lime ha-1 for the soil. Vermicompost $\left(<0.25 \mathrm{~mm}\right.$ sieve) with 0,5 , and 10 tons ha ${ }^{-1}$ rates and inorganic $\mathrm{P}$ at the rates of $0,74.51$ and $149.01 \mathrm{~kg} \mathrm{P}^{-1}$ were prepared for incubation. Accordingly the respective integrated or separate amendments were thoroughly mixed with a given amount of soil and homogenized and the incubation study was conducted for eight weeks as described underneath. A factorial combination of vermicompost $(0,5$ and 10 tons ha-1 soil), lime ( $0,5.93$, 9.57 and 11.96 tons ha-1 soil) and inorganic $P\left(0,74.51\right.$ and $149.01 \mathrm{~kg} \mathrm{P} \mathrm{ha}^{-1}$ soil) was executed to find out the interaction effects of the treatments in charge. The experiment was laid down in a completely randomized design (CRD) with three replications. Consequently, to the three hundred grams of surface (0-15 $\mathrm{cm}$ ) air-dried soil $(<2 \mathrm{~mm})$, the specified amount of lime, vermicompost $(<0.25 \mathrm{~mm})$ and solid triple super phosphate (TSP) (sieved $<1 \mathrm{~mm})$ were applied jointly or separately. The amended soils were then mixed thoroughly and moistened to field capacity and incubated. Few small holes were made in each container to permit aerobic conditions during incubation. Soil samples were then removed for analysis at 60 days. 
The study was a factorial experiment in completely randomized design (CRD) with three factors, namely, organic amendments (vermicompost), lime and mineral P. Statistical analysis of the data including Pearson's simple correlation coefficient, analysis of variance (ANOVA) and comparison of means was executed using Statistical Analysis System (SAS) version 9.1 (SAS Institute, 2004).

\section{Results And Discussion}

\section{Physicochemical properties of experimental soil}

Table 1 Selected characteristics of the experimental soil

\begin{tabular}{|c|c|}
\hline Parameters & Soil (SC1) \\
\hline Soil group & Nitisol \\
\hline Sand $(\%)$ & 23.2 \\
\hline Silt (\%) & 28.6 \\
\hline Clay (\%) & 48.2 \\
\hline Bulk density $\left(\mathrm{gcm}^{-1}\right)$ & 1.32 \\
\hline Field capacity (\%) & 29.5 \\
\hline Permanent wilting point (\%) & 19.6 \\
\hline $\mathrm{pH}(\mathrm{H} 2 \mathrm{O})$ & 4.65 \\
\hline Cation exchange capacity $\left(\mathrm{cmol}_{\mathrm{c}} \mathrm{kg}^{-1}\right)$ & 21.15 \\
\hline Exchangeable acidty $\left(\mathrm{cmol}_{\mathrm{c}} \mathrm{kg}^{-1}\right)$ & 3.76 \\
\hline Exchangeable $\mathrm{Al}\left(\mathrm{cmol}_{\mathrm{c}} \mathrm{kg}^{-1}\right)$ & 2.54 \\
\hline Organic carbon (\%) & 1.58 \\
\hline Mehlich-III P (mg kg $\left.{ }^{-1}\right)$ & 8.09 \\
\hline Alox $\left(\mathrm{mmolkg}{ }^{-1}\right)$ & 147.37 \\
\hline Feox $\left(\mathrm{mmolkg}^{-1}\right)$ & 174.69 \\
\hline Phosphorous sorption Capacity (PSC) (mg P Kg ${ }^{-1}$ ) & 133.54 \\
\hline
\end{tabular}

Source: Ayenew et al. (2018b)

\section{Vermicompost compositions}

The vermicompost that has been harvested after sixty days of decomposition was dark brown in color. As depicted in Table 2 the vermicompost prepared by using parthinium, wheat straw, cow dung and poultry manure as a substrate had a pH value of 8.63. Therefore, the $\mathrm{pH}$ value obtained for the vermicompost verifies that it could be used for liming the soil. The vermicompost was analyzed for nutrients concentrations and the corresponding values were found $\mathrm{N}$ (2.41\%), OC (24.40\%), and C:N (10.12), P (109.23 ppm), K (577.54 ppm ), Ca (1198.28 ppm ), Na (127.12 ppm ), Mg (137.20 ppm ).

Table 2 Characterization of vermicompost

\begin{tabular}{|c|c|c|c|c|c|c|c|c|c|}
\hline Treatments & $\mathrm{pH}$ & $\mathrm{OC}$ & $\mathrm{N}$ & $\mathrm{P}$ & $\mathrm{K}$ & $\mathrm{Na}$ & $\mathrm{Ca}$ & $\mathrm{Mg}$ & C:N \\
\hline & & \multicolumn{2}{|c|}{$\ldots . .(\%) \quad \ldots \ldots}$. & \multicolumn{4}{|c|}{$\left(\mathrm{mg} \mathrm{kg}^{-1}\right)$} & & \\
\hline VC & 8.68 & 24.40 & 2.41 & 109.23 & 577.54 & 133.92 & 1198.28 & 137.20 & 10.12 \\
\hline
\end{tabular}

$\mathrm{OC}=$ organic carbon, $\mathrm{VC}=$ Vermicompost

\section{pH, exchangeable acidity, CEC and available $\mathrm{P}$ after Incubation}

After eight weeks incubation period the soil was found to have $\mathrm{pH}$ ranging from 4.68 to 6.73 (Table 3). It is generally believed that applications of organic materials reduce $\mathrm{pH}$ of a soil (Abdala et al. 2015). However, contrary to the general contemplation, the results of the present study confirmed that application of vermicompost resulted in higher and significant effect on the $\mathrm{pH}$ of studied soils as compared to the control treatment (Table 3 ). The alkaline reaction in 
vermicompost, and the presence of strongly soluble cations in higher concentrations might have contributed to lessening acidic reactions of the soil. In addition, decomposition of vermicompost in soil during incubation might have produced soluble organic acids, which could interact with soil through the oxyhydroxide functional group of clay surfaces and release $\mathrm{OH}^{-}$to soil solution. Similar results have been reported that vermicompost application alone could have increased the pH of the soil (Gopinath and Mina 2011; Gopinath, et al. 2011, Ilker and Tavali 2014).

Analysis of variance also revealed that the application of inorganic $\mathrm{P}$ alone had no significant effect on pH of the soil; however the interaction of two factors (lime $\mathrm{x}$ inorganic $\mathrm{P}$, lime $\mathrm{x}$ vermicompost, inorganic $\mathrm{P} x$ vermicompost) and three factors (vermicompost $\mathrm{x}$ inorganic $\mathrm{P} x$ lime) influenced significantly the $\mathrm{pH}$ of the soil (Tables 3). Furthermore, the highest pH (6.73) value of the soil was recorded at combined application of lime, vermicompost and inorganic $\mathrm{P}$ (lime $\mathrm{x}$ vermicompost $x$ inorganic $P$ ) in a proportion amounted 11.50 ton $\mathrm{CaCO}_{3} \mathrm{ha}^{-1}, 10$ ton $\mathrm{VC} \mathrm{ha}^{-1}$ and $149.01 \mathrm{~kg} \mathrm{P}^{-1}$ whilst, the lowest pH value (4.68) was achieved from the control. The findings of the present study was in concurrent with that of Ashoka et al. (2014) which reported addition of inorganic P alone did not have any appreciable effect on soil pH values.

The acidity reduced by lime, vermicompost and inorganic $\mathrm{P}$ was synergistic having a mechanism that calcium from lime replaces the exchangeable forms of $\mathrm{Al}$ and Fe, which reacts with hydroxide ion released from water in the soil solution forming insoluble Al and Fe hydroxides (Buni, 2015); while compost forms insoluble $\mathrm{Al}$ and Fe organic acid complex bounding to the exchangeable Al and Fe (Haynes and Mokolobate 2001). In the meantime, the adsorption of the added phosphate at the exchange site might have contributed to the raise in $\mathrm{pH}$ of the studied soil through ligand exchange. In agreement with this, a study revealed that there was a steady increase in the $\mathrm{pH}$ of the supernatant solution as sorption progressed, because sorption occurs by the replacement of hydroxyl groups, exposed on surface sites, by phosphate in solution (Goldberg et al. 2008).

The results obtained after eight weeks incubation period showed that the amount of available P extracted by Mehlich-III, method ranged from 8.77 to 21.89 $\mathrm{mg} \mathrm{kg}^{-1}$ at SC1 study site (Table 3). Analysis of variance also revealed that the main factors (vermicompost and inorganic P) applied to soil significantly increased Mehlich-III P content of the soil compared to the control treatment. Similar results have been reported by Ilker and Tavali (2014) showing that vermicompost applied to soil significantly increased available phosphorous. Moreover, statistically significant $(P<0.05)$ influences were observed whenever the three factors are interacted (vermicompost $x$ lime $x$ inorganic $P$ ). Consequently, the highest $\left(21.89 \mathrm{mg} \mathrm{kg}^{-1}\right)$ value of Mehlich-III $\mathrm{P}$ was recorded when vermicompost was applied in combination with lime and inorganic $\mathrm{P}$ at the rates of 10 ton $\mathrm{VC} \mathrm{ha-1}, 9.20$ ton $\mathrm{CaCO}_{3}$ ha $^{-1}$ and $149.01 \mathrm{~kg} \mathrm{P}^{-1}$, while the lowest $\left(8.77 \mathrm{mg} \mathrm{kg}^{-1}\right)$ was recorded from the control. The compelling reason for the enhanced increase in available P of soils after incubation could be due to with ability of the lower molecular organic acids (decomposition product of vermicompost) and their anionic carboxylate functional groups to interact with soil, by occupying P adsorption sites and competing with phosphate (Guppy et al. 2005). The increased amount of phosphate adsorbed on free metal oxyhydroxides and the presence of soluble cations in lime and vermicompost, which displace acidic caions, might have triggered the availability of $\mathrm{P}$. In harmony with this, Kamprath (1984) reported that the $\mathrm{Ca}^{2+}$ in lime, and $\mathrm{Ca}^{2+}, \mathrm{K}^{+}, \mathrm{Na}^{+}$in vermicompost (organic matter) could displace $\mathrm{Al}^{3+}, \mathrm{Fe}^{2+}$ and $\mathrm{H}^{+}$ions from the soil sorption sites, so that $\mathrm{P}$ fixation would be reduced.

The increase in soil pH was reflected by corresponding decrease in exchangeable acidity from $2.57 \mathrm{cmol}_{\mathrm{C}} \mathrm{kg}^{-1}$ in control to $0.31 \mathrm{cmol}_{\mathrm{C}} \mathrm{kg}^{-1}(P<0.05)$. The main factors (lime, vermicompost and inorganic $\mathrm{P}$ ), the interaction between two factors (lime $\mathrm{x}$ inorganic $\mathrm{P}$, vermicompost $\mathrm{x}$ lime, inorganic $\mathrm{P} x$ vermicompost) and three factors (lime $x$ vermicompost $x$ inorganic $P$ ) significantly altered the levels of exchangeable acidity in the studied soil (Tables 3 ). Moreover, the greatest (87.94\%) change was obtained from the integrated applications of lime, vermicompost and inorganic $\mathrm{P}$ at the rates of $\left(11.50\right.$ ton ha ${ }^{-1}, 10$ ton $\mathrm{VC}$ ha ${ }^{-1}$, $149.01 \mathrm{~kg} \mathrm{P} \mathrm{ha}^{-1}$ ), while the lowest (1.53\%) was recorded from the control the soil. The reduction in exchangeable acidity can partially be attributed to an initial increase in soil $\mathrm{pH}$ that was observed with lime and vermicompost.

Similar analysis showed that except for the sole applications of inorganic $\mathrm{P}$, the other factors including two factors (lime $\mathrm{x}$ inorganic $\mathrm{P}$, vermicompost $\mathrm{x}$ lime, inorganic $\mathrm{P} x$ vermicompost) and three factors interactions (lime $\mathrm{x}$ vermicompost $\mathrm{x}$ inorganic $\mathrm{P}$ ) had significant decreasing effects on exchangeable aluminum. It could also be noted that the three factors interaction appeared to have a significant effect and decreased the exchangeable Al of the soil by 88.09 to $95.23 \%$ compared to the control, indicating the synergistic effects of the three factors on the exchangeable aluminum in the studied soil. An increase in soil pH might have resulted in precipitation of exchangeable and soluble Al, as insoluble Al hydroxides (Ritchie 1994), thus reducing concentration of Al in soil solution. However, there are other mechanisms involved in the reactions of Al with OM, which are intricate and probably involve complex formation with low-molecular weight organic acids, such as citric, oxalic, and malic acids, and humic material produced during the decomposition of the OM and adsorption of Al onto the decomposing organic residues (Ritchie, 1994). In agreement with this result, Teshome et al. (2017) reported that integrated application of lime, mineral $\mathrm{P}$ and compost had reduced the exchangeable aluminum, due to the formation of organo-Al (chelation) complexes, insoluble aluminum hydroxide precipitate, and aluminum phosphate precipitate from compost, lime and inorganic $P$ respectively.

As far as CEC of the soil is concerned, the interactions of three factors had significant $(P<0.01)$ influence on the CEC of the soil (Tables 3$)$. After eight weeks incubation period, CEC values of the soil was found in the range of $22.05 \mathrm{cmol}_{\mathrm{C}} \mathrm{kg}^{-1}$ (control) and $29.53 \mathrm{cmol}_{\mathrm{C}} \mathrm{kg}^{-1}$ in combined applications of vermiccompost, lime and inorganic $\mathrm{P}$ at the rates of 10 ton $\mathrm{VC} \mathrm{ha}{ }^{-1}, 11.50$ ton $\mathrm{CaCO}_{3} \mathrm{ha}^{-1}$, and $149.01 \mathrm{~kg} \mathrm{P}$ ha $^{-1}$. Sole applications of inorganic $\mathrm{P}$ had no significant effect on CEC of incubated soil (Table 3). The possible reason for the enhancement of CEC during combined (lime $\mathrm{x}$ vermicompost $\mathrm{x}$ inorganic $\mathrm{P}$ ) application of those amendments could be the increase in $\mathrm{pH}$ of the soils. Because with increasing $\mathrm{pH}$ (i.e. increasing activity of $\mathrm{OH}^{-}$ions) $\mathrm{H}^{+}$is dissociated from oxide surfaces or from organic functional groups, thus resulting in a negative charge, which could be allied with the CEC of the soils. 


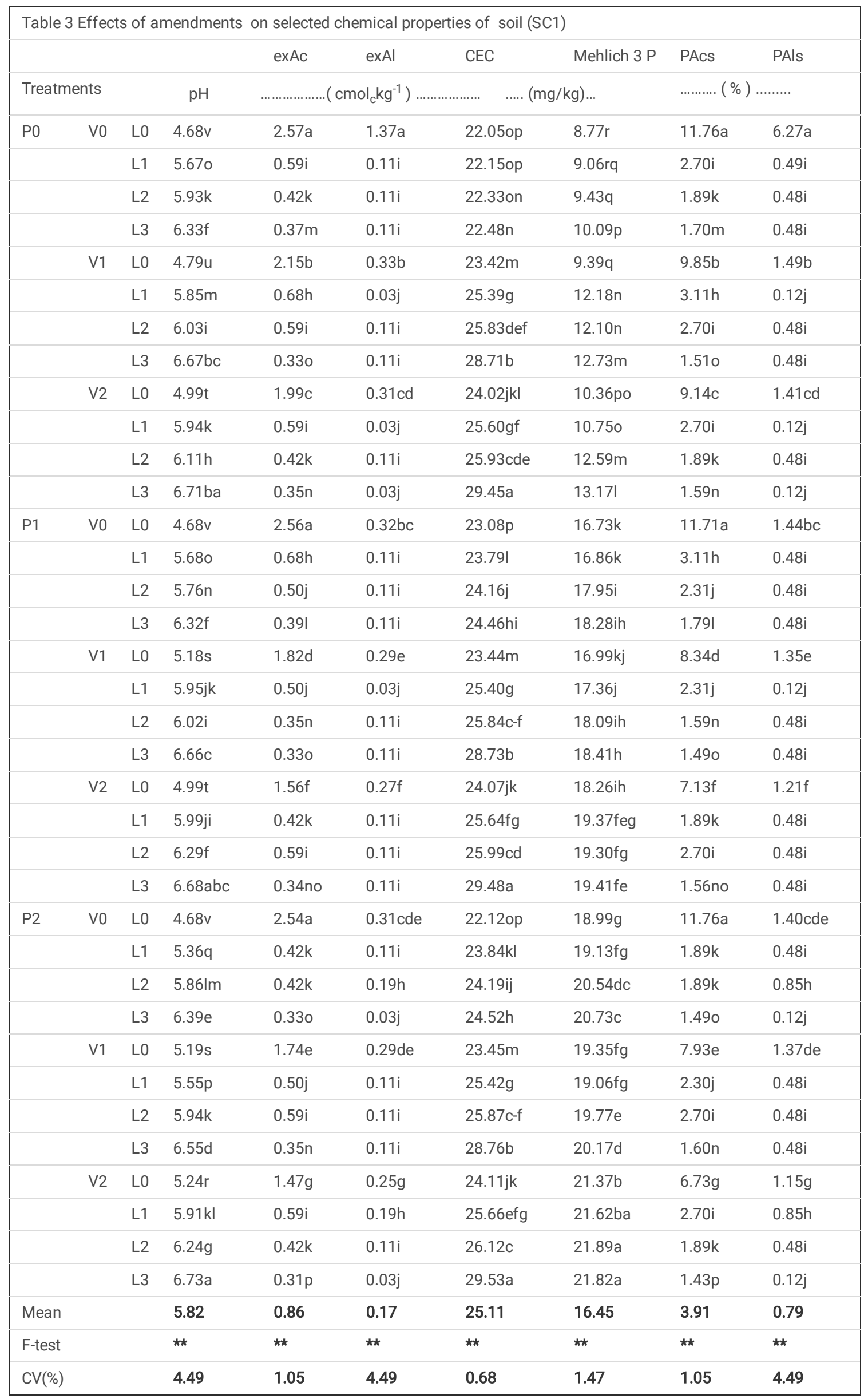


Means followed by the same letter within a column are not significantly different; $*$ * = significant at $\mathrm{P} \leq 0.01$ using the Duncan's multiple range test; $\mathrm{CV}=$ coefficient of variation of treatments; exAc = exchangeable acidity; exAl = exchangeable Al; PAcs = percentage of acid saturation; PAls = percentage of Al saturation; L0 = No lime; L1 = 5.93 tons lime ha ${ }^{-1} ; \mathrm{L} 2=9.57$ tons lime ha ${ }^{-1} ; \mathrm{L} 3=11.96$ tons lime ha ${ }^{-1} ; \mathrm{V} 0=$ No vermicompost; $\mathrm{V} 1=5$ tons vermicompost ha ${ }^{-1}$; $\mathrm{V} 2=10$ tons vermicompost ha- ${ }^{-1} ; \mathrm{P} 0=$ No mineral $\mathrm{P} ; \mathrm{P} 1=74.51 \mathrm{~kg} \mathrm{P} \mathrm{ha}^{-1} ; \mathrm{P} 2=149.01 \mathrm{~kg} \mathrm{P} \mathrm{ha}^{-1}$.

\section{Amendments effect on oxalate and dithionite extractable $\mathrm{P}, \mathrm{Al}$ and Fe}

Data revealing the distribution of extractable P, Fe and Al after eight weeks incubation of the soil is presented in Tables 4 . In view of a study results reported by Asmare et al. (2015) on eight Ethiopian acidic soils the soil considered in the current study had high oxalate extractable Al and Fe and dithionite citrate bicarbonate extractable Al and Fe (Ayenew et al. 2018a). Since oxalate and dithionite extractable iron and aluminum contents of the soil were high; Fe and Al oxyhydroxides could be the dominant species with which P interacts. The changes in some of the properties of soil upon applications of amendments might be ascribed to the change in concentration of the extractable form of Fe and Al present in the soil (Table 4). As a case in point, Torrent et al. (1990) reported that the nature, amount and distribution of iron and aluminum oxides in soil affect the ionic charge, chemical characteristics, and ion adsorption especially phosphorous sorption.

Data showing main and interaction effects of treatments on oxalate extractable aluminium ( $\left.\mathrm{Al}_{\mathrm{ox}}\right)$ are exhibited in Table 4 . The highest (152.64 mmol $\left.\mathrm{kg}^{-1}\right)$ value of $\mathrm{Al}_{\mathrm{ox}}$ from sole application of vermicompost at the rate of 10 ton ha-1 and the least $\left(141.93 \mathrm{mmol} \mathrm{kg}^{-1}\right)$ from the integrated applications of lime, vermicompost and inorganic $\mathrm{P}$ were recorded for the soil. Thus, the highest (6.85\%) reduction in oxalate extractable Al was obtained from combined applications of lime, vermicompost and inorganic $\mathrm{P}$ at the rates of 9.20 ton $\mathrm{CaCO}_{3} \mathrm{ha}^{-1}, 10$ ton $\mathrm{VC} \mathrm{ha}{ }^{-1}$ and $149.01 \mathrm{~kg} \mathrm{P}$ ha-1 $^{-1}$. After a given incubation period the results of analysis of variance revealed that sole (inorganic $P$, lime and vermicompost), combined applications of the ammendments had significant $(p<0.01)$ effect on the oxalate extractable aluminum over the control (Table 4).

The effects of treatments on dithionite citrate bicarbonate extractable aluminium ( $\mathrm{Al} \mathrm{d}_{\mathrm{d}}$ ) are also presented in Table 4. In the interim sole and integrated applications of amendments had substantial $(p<0.01)$ influence on dithionite citrate bicarbonate extractable aluminum $\left(A l_{d}\right)$. Consequently, the highest (173.77 mmol kg-1 dithionite citrate bicarbonate extractable $\left(\mathrm{Al}_{\mathrm{d}}\right)$ value was obtained from the control while the lowest $\left(169.23 \mathrm{mmol} \mathrm{kg}^{-1}\right)$ attained from pooled applications of lime, vermicompost and inorganic $\mathrm{P}$ at the rates of 9.20 ton $\mathrm{CaCO}_{3} \mathrm{ha}^{-1}, 10$ ton VC ha-1 and $149.01 \mathrm{~kg} \mathrm{P} \mathrm{ha}^{-1}$.

The effects of treatments on oxalte extractable iron $\left(\mathrm{Fe}_{\mathrm{ox}}\right)$ are also shown in Table 4. The values of $\mathrm{Fe}_{\mathrm{ox}}$ obtained after incubation was ranged from 88.59 $96.39 \mathrm{mmol} \mathrm{kg}^{-1}$ in which the maximum $\left(96.39 \mathrm{mmol} \mathrm{kg}^{-1}\right)$ was recorded from the application of vermicompost at the rate of 10 ton ha-1 alone and the least $\left(88.59 \mathrm{mmol} \mathrm{kg}^{-1}\right)$ recorded from the integrated applications of lime vermicompost and inorganic $\mathrm{P}$ at the highest rates. The highest value obtained from sole application of vermicompost may be ascribed to organo-metal complex formed during the incubation period. It has been reported that in Fe- and Al-rich soil, organic matter could inhibit the crystallization of Al and Fe by forming stable complexes with them, which in turn can increase P sorption as noncrystalline Al and Fe increases (Kang et al. 2009). A significant $(\mathrm{p}<0.01)$ decreases in oxalate $\left(\mathrm{Fe}_{\mathrm{ox}}\right)$ and dithionite extractable iron $\left(\mathrm{Fe}_{\mathrm{d}}\right)$ were observed as a result of integrated applications of lime, vermicompost and inorganic $\mathrm{P}$ as two factors (lime $\mathrm{x}$ inorganic $\mathrm{P}$, lime $\mathrm{x}$ vermicompost, inorganic $\mathrm{P} x$ vermicompost) and three factors (vermicompost $x$ lime $x$ vermicompost $x$ inorganic $P$ ) compared to the control. Accordingly, the maximum (9.32\%) reduction in Fe $\mathrm{ox}$ at the exchange sites was recorded from integrated applications of lime, vermicompost and inorganic $\mathrm{P}$ at the rates of 11.50 ton $\mathrm{CaCO}_{3} \mathrm{ha}^{-1}, 10$ ton VC ha-1 and $149.01 \mathrm{~kg} \mathrm{P}^{-1}$ $\mathrm{ha}^{-1}$ respectively, whereas the least (1.34\%) was obtained from the sole application of vermicompost at the rates of 10 tone ha-1.

Similarly, amalgamated applications of these amendments at the rates of 11.50 ton $\mathrm{CaCO}_{3} \mathrm{ha}^{-1}, 10$ ton VC ha ${ }^{-1}$ and $149.01 \mathrm{~kg} \mathrm{P}^{-1}$ had brought the maximum (1.73\%) reduction in $\mathrm{Fe}_{\mathrm{d}}$, and the least (0.16\%) variation from the control compared to the native soil. Similar results were reported by Asmare et al. (2015) who found that individual and combined applications of organic and inorganic minerals had significant effect on oxalate $\left(\mathrm{Al}_{\mathrm{ox}}, \mathrm{Fe}_{\mathrm{ox}}\right)$ and dithionite $\left(\mathrm{Al}_{\mathrm{d}}, \mathrm{Fe}_{\mathrm{d}}\right)$ extractable aluminum and iron free oxides.

It could be noted that synergistic effects of the three factors on the oxalate and dithionite extractable Fe and Al were remarkable. This might have occurred through different reaction mechanisms like the liming effect which develops negative charge through abstraction of $\mathrm{H}^{+}$by $\mathrm{OH}^{-}$ions and $\mathrm{Ca}^{+2}$ ions displacement of $\mathrm{Al}$ at the exchange sites forming insoluble precipitates $\mathrm{Al}(\mathrm{OH})_{3}$ as a result of applications of liming materials. Additionally, formations of organo-metal complexes from soluble organic molecules that arouse from organic amendments could in turn occupy the exchange sites and inhibit the interaction between the metallic oxyhdroxides and oxalate extractants. Furthermore, adsorption reaction through which soil interacts with foreign materials; i.e along with the application of inorganic $P$ the amount of phosphate adsorbed on metal oxyhydroxides increased and this could reduce free metallic oxides at exchange sites. In this regard, the results of the present study were in concomitant with that of Asmare et al. (2015), in which the reductions in $\mathrm{Al}_{\text {ox }}, \mathrm{Fe}_{\mathrm{ox}}, \mathrm{Al}_{\mathrm{d}}$ and $\mathrm{Fe}_{\mathrm{d}}$ contents as the result of application of $\mathrm{P}$ bearing materials to a soil was reported and justified by the fixation of $\mathrm{Al}$ and Fe in the form of Al-P and Fe-P as a cause for reduction in amount extracted by oxalic acid.

Ammonium oxalate extractable phosphorous is associated with oxalate extractable iron and aluminum, because Fe and Al oxyhydroxides are good indicators for $P$ sorption as they act as a sink for soluble phosphates (Vaananen et al. 2008). It is a potentially useful measure of the $P$ associated with the amorphous iron and aluminum oxides in the soil (Wolf and Baker 2008). In the current study, upon the exclusive (main factor), integrated [two factors (lime $x$ vermicompost, inorganic $\mathrm{P} x$ lime, vermicompost $\mathrm{x}$ inorganic $\mathrm{P}$ ) and three factors (lime $\mathrm{x}$ vermicompost $\mathrm{x}$ inorganic $\mathrm{P}$ )] applications to soils for eight weeks incubation period appreciable $(p<0.001)$ differences in oxalate extractable $P\left(P_{\text {ox }}\right)$ were observed in the soil. In the case where integrated application of amendments (lime $x$ vermicompost $x$ inorganic $P$ ) at the rates of 11.50 ton $\mathrm{CaCO}_{3}$ ha $^{-1}, 10$ ton $\mathrm{VC} \mathrm{ha}{ }^{-1}$ and $149.01 \mathrm{~kg} \mathrm{P}^{-1}$ was executed, the highest (8.70 
mmol kg ${ }^{-1}$ ) was achieved whereas the lowest $\left(5.88 \mathrm{mmol} \mathrm{kg}^{-1}\right)$ recorded from the control. It can be observed that as the amount of oxalate and dithionite extractable form of those metal oxides reduced from the exchange sites, phosphorous extracted by ammonium oxalate $\left(P_{\text {ox }}\right)$ obviously enhanced. Similar to the present study, it has been noted that sole or integrated applications of $\mathrm{P}$ sources (organic and inorganic) had a significant effect on the oxalate extractable Al and Fe (Gikonyo et al. 2011) which in turn influence $\mathrm{P}_{\text {ox }}$, since $\mathrm{P}$ adsorbed by soil mainly attributed to $\mathrm{P}$ adsorbed on amorphous metal oxides (Fe $\mathrm{ox}_{\text {and }}$ $\mathrm{Al}_{\mathrm{ox}}$ ) (Cui et al. 2017).

Phosphorous sorption capacities was significantly $(P<0.05)$ influenced by the main and joined applications of treatments $(T a b l e ~ 4)$. After the incubation period, the highest sorption capacity was recorded from the soil incubated solely with vermicompost at the rate of 10 ton ha-1 $\left(132.98 \mathrm{mmol} \mathrm{kg}^{-1}\right)$ and the lowest (123.31 mmol kg-1) value was obtained due to combined applications of the treatments (lime $x$ vermicompost $x$ inorganic $P$ ) at the rates of 9.20 ton $\mathrm{CaCO}_{3} \mathrm{ha}^{-1}, 10$ ton $\mathrm{VC} \mathrm{ha}{ }^{-1}$, and $149.01 \mathrm{~kg} \mathrm{P} \mathrm{ha}^{-1}$. It can also be seen that the adsorption capacity of the soil decreased significantly with increasing applications rates of integrated amendments while applications of vermicompost solely increased the sorption capacity of the two soils under study. The increased adsorption capacity of the soil because of the exclusive application of vermicompost may be due to hindrance of crystallization of Fe and Al oxides. In Fe and Al rich soil, organic matter could inhibit the crystallization of $\mathrm{Al}$ and Fe by forming stable complexes with them, which in turn can increase $\mathrm{P}$ sorption as non-crystalline Al and Fe increases (Borggaard et al. 1990; Kang et al. 2009). The reduction in magnitude of phosphorous sorption capacities due to integrated application could be attributed to the coating of metal oxyhydroxides species by organic molecules from vermicompost applications, which reduce the availability of binding sites for phosphate ions, formations of insoluble aluminum hydroxides from the applications of lime, which reduces adsorptions of phosphate on the exchange site and addition of inorganic $P$, which occupy the exchange sites where $P$ is expected to be adsorbed. Thus, the result of the present study is in concurrent with the study made by Gikonyo et al. (2011), which showed that sole or integrated applications of P sources (organic and inorganic) had a significant effect on the PSC of a soil.

The change in DPS of the soil was presented in Table 4. The phosphate ion is negatively charged and hence, continued P fixation leads to a "semi-permanent" increase in surface negative charge, resulting in a decrease in the electric potential of the reacting soil particle (Barrow et al. 1998; Celi et al. 2000).

Consequently, increasing P saturation leads to weaker and weaker retention of P, implying that the degree of phosphorus saturation (DPS) appears to govern solution P concentration (Magdoff et al., 1999). Furthermore, recent studies have shown that the degree of P saturation (DPS) is a good indicator of the soil's potential to release $\mathrm{P}$ (Hooda et al., 2000).

The incubated soil was found to have DPS (\%) values ranging from 4.49-7.06\%. The DPS (\%) value was significantly ( $<<0.01)$ affected by individual (lime, vermicompost, inorganic P) and combined applications of these treatments (Table 4). The maximum DPS (7.06\%) value was recorded from the integrated applications of (lime $x$ vermicompost $x$ inorganic $P$ ) amendments at the rates of 11.50 ton $\mathrm{CaCO}_{3} \mathrm{ha}^{-1}, 10$ ton VC ha ${ }^{-1}$, and $298.03 \mathrm{~kg} \mathrm{P}^{-1}$. Whereas the minimum DPS (4.49\%) value was observed from the control, Thus, the result of present study is in concurrent with the study made by Gikonyo et al. (2011) which showed that sole or integrated applications of P sources (organic and inorganic) had a significant effect on the DPS of soils. It can be inferred that the observed increase in the DPS of the soils as a result of application of these amendments might have brought the better mobility of $\mathrm{P}$ in the soils. In this regard Yan et al. (2017) reported that due to decrease of the sorption sites for further P sorption, the concentrations of exchangeable P increased with increasing DPS and soil P mobility increases. 


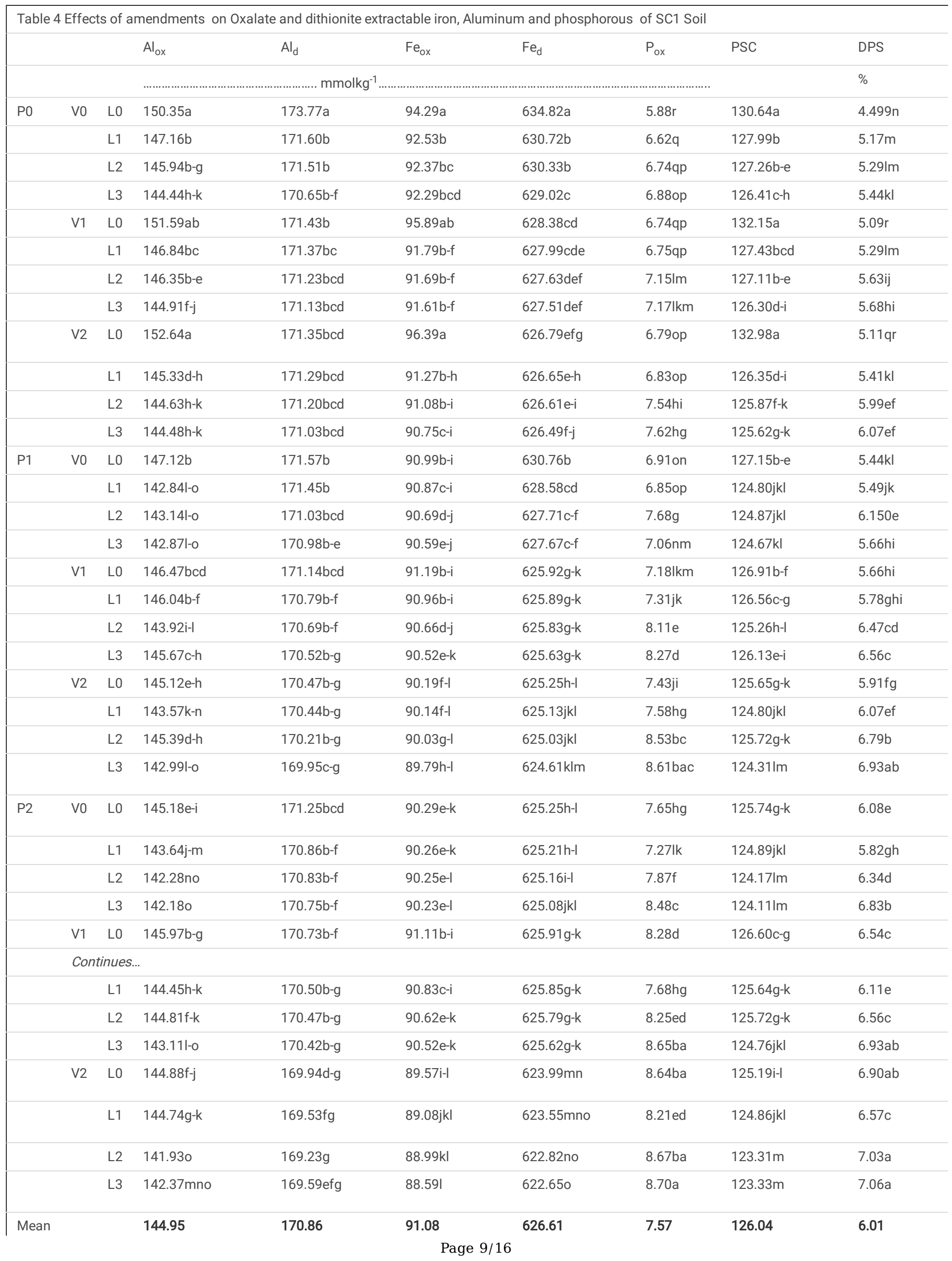




\begin{tabular}{|llllllll} 
F-test & $* *$ & $* *$ & $* *$ & $* *$ & $* *$ & $* *$ & \\
CV & 0.74 & 0.41 & 1.12 & 0.12 & 1.17 & 0.72 & 1.83 \\
\hline
\end{tabular}

Means followed by the same letter within a column are not significantly different; $* \star$ = significant at $\mathrm{P} \leq 0.01$ using the Duncan's multiple range test; $\mathrm{CV}=$ coefficient of variation of treatments; exAc = exchangeable acidity; exAl = exchangeable Al; PAcs = percentage of acid saturation; PAls = percentage of $\mathrm{Al}$

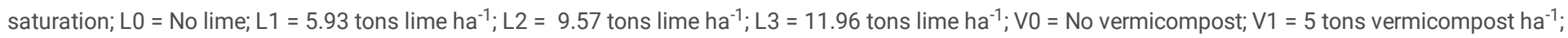
$\mathrm{V} 2=10$ tons vermicompost ha- ${ }^{-1} ; \mathrm{P} 0=$ No mineral $\mathrm{P} ; \mathrm{P} 1=74.51 \mathrm{~kg} \mathrm{P} \mathrm{ha}^{-1} ; \mathrm{P} 2=149.01 \mathrm{~kg} \mathrm{P} \mathrm{ha}^{-1}$.

\section{Amendments effect on forms and distributions of $P$}

The combined and sole applications of the amendments altered significantly the chemical properties expected to impact the distributions of phosphorous in the soil (Table 5). The forms and distribution of the various $\mathrm{P}$ fractions $\left[\mathrm{NH}_{4} \mathrm{Cl}-\mathrm{P}, \mathrm{NaHCO}_{3}-\mathrm{Pi}, \mathrm{NaHCO}_{3}-\mathrm{Po} \mathrm{NaOH}-\mathrm{Pi}, \mathrm{NaOH}-\mathrm{Po}(\mathrm{NaOH}-\mathrm{Pi})_{\mathrm{sn}},(\mathrm{NaOH}-\mathrm{Po})_{\mathrm{sn}} \mathrm{HCl}-\mathrm{Pi}\right.$, residual $\mathrm{P}$ and total $\mathrm{P}$ ] following incubation of the soil are shown in Table 5 too. After eight weeks incubation period, the distributions and forms of $\mathrm{Pi}$ were in the order of magnitude: $\mathrm{NH}_{4} \mathrm{Cl}-\mathrm{P}<\mathrm{NaHCO}_{3}-\mathrm{Pi}<(\mathrm{NaOH}-\mathrm{Pi})_{\mathrm{sn}}<\mathrm{HCl}-\mathrm{Pi}<\mathrm{NaOH}-\mathrm{Pi}$. The highest percentage change in each fraction was recorded from the interactions of three factors ( $\lim x$ vermicompost $x$ inorganic $P$ ) whereas; the lowest was obtained from the control. Results of the analysis of variance also indicated that integrated applications of both two factors (lime $x$ vermicompost $x$ inorganic $P$ ) and three factors (lim $x$ vermicompost $x$ inorganic $P$ ) amendments had statistically significant $(\mathrm{P}<0.01)$ effect on the amount and distributions of $\left.\mathrm{NH}_{4} \mathrm{Cl}-\mathrm{P}, \mathrm{NaHCO}-\mathrm{Pi}, \mathrm{NaOH}-\mathrm{Pi}\right) \mathrm{sn}, \mathrm{HCl}-\mathrm{Pi}$, and $\mathrm{NaOH}-\mathrm{Pi}$ fractions in the soil.

The distributions of easily mineralisable $\left(\mathrm{NaHCO}_{3}\right)-\mathrm{Po}$ and less labile $(\mathrm{NaOH})-\mathrm{Po}$ were in the order of magnitude: $\mathrm{NaOH}-\mathrm{Po}<(\mathrm{NaOH}-\mathrm{Po})_{\mathrm{sn}}<\mathrm{NaHCO}{ }_{3}-\mathrm{Po}$. The highest percentage change in each fraction was recorded from the interactions of three factors (lime $\mathrm{x}$ vermicompost $\mathrm{x}$ inorganic $\mathrm{P}$ ) and the lowest was obtained from the control. According to analysis of variance all the treatments influenced significantly $(p<0.01)$ the amount and distributions of the extracted organic form of $\mathrm{P}$ (Tables 5$)$.

The $\mathrm{NaOH}-\mathrm{Pi}$ was the largest extractable inorganic $\mathrm{P}$ fraction and the most abundant active $\mathrm{P}$ form contributing to about $22.66-45.49 \%$ and $17.76-42.07 \%$ of the total $\mathrm{P}$, in the studied soil. Thus, $\mathrm{NaOH}-\mathrm{P}$ was the major sink for the applied P. Previous studies also reported that organic amendments with high $\mathrm{P}$ contents could significantly increase $\mathrm{NaOH}-\mathrm{Pi}$ contents (and to a lesser extent $\mathrm{NaOH}-\mathrm{Po}$ ) (lyamuremye et al. 1996; Li et al. 2015). The increase of this fraction observed in these soils amended by phosphorus fertilizer and vermicompost was possibly as a result of phosphate released from phosphorus fertilizer and vermicompost. Similar result has been reported by Pavan and Andmcioli (1995) where application of compost was able to promote NaOH-Pi. It can be deduced that since $\mathrm{NaOH}-\mathrm{Pi}$ fraction is a site for $\mathrm{P}$ sorption; increase in this fraction provide evidence that P-rich amendments in the studied soil may decrease future P sorption in soil by reacting with these sorption sites (Daly et al. 2001; Yan et al. 2013). This result is also in concomitant with what has been reported by Elias et al. (2010) that goat manure and inorganic phosphate addition influenced $\mathrm{NaOH}-\mathrm{P}_{\mathrm{i}}$ to greater extent.

After eight weeks of incubation period the least $\left(2.04 \mathrm{mg} \mathrm{kg}^{-1}\right)$ concentration of the readily available $\mathrm{NH}_{4} \mathrm{Cl}$ extractable $\mathrm{P}$ (Gunatilaka, 1988), was recorded from the control and the highest (33.37 $\mathrm{mg} \mathrm{kg}^{-1}$ ) was obtained from the combined applications of lime, vermicompost and inorganic $\mathrm{P}$ at the rates of 11.50 ton $\mathrm{CaCO}_{3}$ ha $^{-1}, 10$ ton $\mathrm{VC} \mathrm{ha}{ }^{-1}, 149.01 \mathrm{~kg} \mathrm{Pha}^{-1}$ respectively.

According to the result of the present study (Table 5) lime alone had no significant effect on readily available fractions $\left(\mathrm{NH}_{4} \mathrm{Cl}-\mathrm{P}\right)$ at both study sites. Contrasting result was mentioned by Hartono et al. (2000) that lime had significant effect on readily available Pi but it agrees with that of lyamuremye et al. (1996) where lime didn't affect readily available $\mathrm{Pi}$. Even though sole applications of lime didn't appreciably affect the readily available fractions of $\mathrm{P}\left(\mathrm{NH}_{4} \mathrm{Cl}\right.$ $\mathrm{P})$ the magnitude of enhancement varied along with the rates of lime. This change in magnitude may be attributed to the decrease of exchangeable Al that is precipitated by $\mathrm{OH}^{-}$. In the case where lime was applied in combination with other materials like inorganic $\mathrm{P}$ and vermicompost, significant differences were observed over the control (Table 5). On the other hand, the readily available fraction $\left(\mathrm{NH}_{4} \mathrm{Cl}-\mathrm{P}\right)$ was significantly affected by single or combined applications of inorganic $\mathrm{P}$ and vermicompost as compared to the control.

The $\mathrm{HCl}-\mathrm{Pi}$ fraction is associated with the primary minerals such as apatite (Tiessen et al. 1984) and with calcium-bound $\mathrm{P}$, which is little or missing in highly weathered soils (Walker and Syers 1976). In the present exploration, it appeared that integrated applications of the amendments of two factors (lime $x$ vermicompost, inorganic $\mathrm{P} x$ lime, vermicompost $\mathrm{x}$ inorganic $\mathrm{P}$ ) and three factors (lime $\mathrm{x}$ vermicompost $\mathrm{x}$ inorganic $\mathrm{P}$ ) tended to enhance $\mathrm{HCl}-\mathrm{Pi}$ significantly (Table 5). Consequently, the highest value of $\mathrm{HCl}$-Pi was recorded from the interaction of lime, vermicompost and inorganic $\mathrm{P}$, at the respective maximum rates, whereas the lowest was recorded from the control. However, in the current study, $\mathrm{HCl}-\mathrm{P}$ did not varied significantly with the sole applications of those treatments. The absence of substantial changes in $\mathrm{HCl}-\mathrm{Pi}$ is explicable because the soil is acidic which would favor formation of $\mathrm{Al}$ and $\mathrm{Fe} \mathrm{P}$ inorganic compounds over Ca products (Hartono et al. 2000). Similar result was reported by Pavan and Androcioli (1995) that application of compost didn't significantly influence $\mathrm{HCl}$-Pi. Hartono et al. (2000) found that applications of inorganic phosphorous or lime to acidic soils had no significant effects on the concentrations of $\mathrm{HCl}-\mathrm{Pi}$.

Generally, the dynamics of the two labile P fractions $\left(\mathrm{NH}_{4} \mathrm{Cl}-\mathrm{P}, \mathrm{NaHCO}_{3}-\mathrm{P}\right.$ ) varied considerably $(\mathrm{p}<0.05)$ when combined applications of lime, vermicompost and inorganic $\mathrm{P}$ were executed at both sampling sites. Whilst, the lower plant available chemisorbed Pi associated with amorphous and crystalline Fe and Al hydroxides and clay minerals ( $\mathrm{NaOH}$-pi) and moderately labile, easily mineralisable $\left(\mathrm{NaHCO}_{3}\right)$-Po and less labile ( $\left.\mathrm{NaOH}\right)$-Po were significantly altered during the incubation period. 


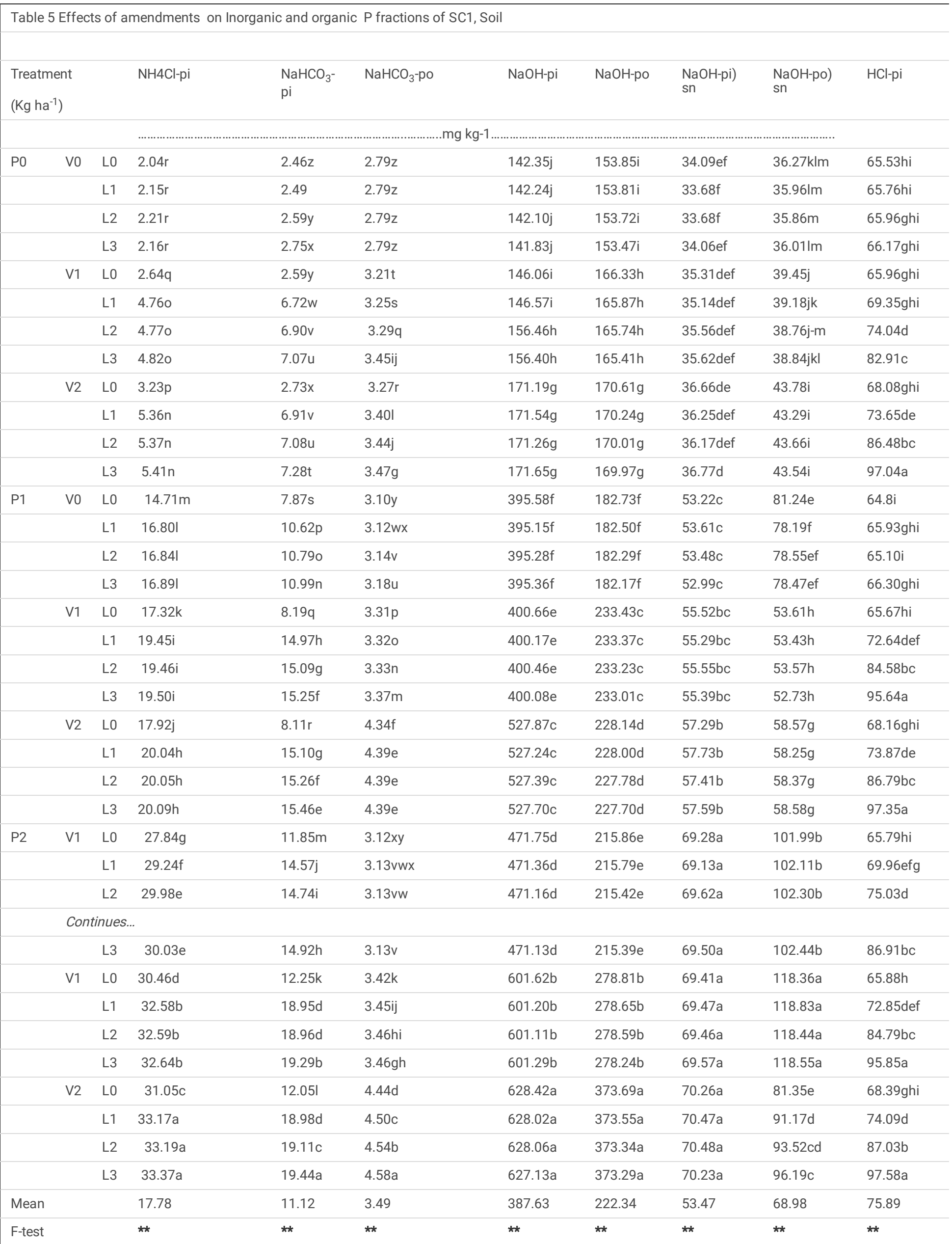




\begin{tabular}{llllllll}
\hline CV\% & 1.46 & 0.39 & 0.21 & 0.42 & 0.74 & 3.07 & 2.65 \\
\hline
\end{tabular}

Means followed by the same letter within a column are not significantly different; ${ }^{*}=$ significant at $\mathrm{P} \leq 0.01$ using the Duncan's multiple range test; $\mathrm{CV}=$ coefficient of variation of treatments; exAc = exchangeable acidity; exAl = exchangeable Al; PAcs = percentage of acid saturation; PAls = percentage of $\mathrm{Al}$ saturation; $L 0=$ No lime; $L 1=5.93$ tons lime ha ${ }^{-1} ; \mathrm{L} 2=9.57$ tons lime ha ${ }^{-1} ; L_{3}=11.96$ tons lime ha ${ }^{-1} ; \mathrm{V} 0=$ No vermicompost; $\mathrm{V} 1=5$ tons vermicompost ha-1; $\mathrm{V} 2=10$ tons vermicompost ha- ${ }^{-1} ; \mathrm{P} 0=$ No mineral $\mathrm{P} ; \mathrm{P} 1=74.51 \mathrm{~kg} \mathrm{P}^{-1} ; \mathrm{P} 2=149.01 \mathrm{~kg} \mathrm{P}^{-1}$.

\section{Correlation among soil properties}

The correlation between soil properties after incubation with amendments is exhibited in Table 6 . The readily available $\mathrm{NH}_{4} \mathrm{Cl}$ extractable $\mathrm{P}$ was strongly positively correlated with Mehlich 3-P, $\mathrm{NaHCO}_{3}-\mathrm{Pi}, \mathrm{NaHCO}_{3}-\mathrm{Po}, \mathrm{HCl}-\mathrm{P}, \mathrm{NaOH}-\mathrm{Pi}, \mathrm{NaOH}-\mathrm{Po}$ and $\mathrm{P}_{\text {ox }}$. This could be an indication for the presence of higher concentration of $\mathrm{NH}_{4} \mathrm{Cl}$ extractable $\mathrm{P}$ in soils where there are prominently higher concentrations of Mehlich $3-\mathrm{P}, \mathrm{NaHCO}-\mathrm{Pi}, \mathrm{NaHCO}-\mathrm{Po}, \mathrm{HCl}-\mathrm{P}, \mathrm{NaOH}-\mathrm{Pi}, \mathrm{NaOH}-$ $\mathrm{Po}$ and $\mathrm{P}_{\mathrm{ox}}$ in the soil. In addition, the correlation result verified the scientific speculation that $\mathrm{P}_{\mathrm{ox}}$ thought to be $\mathrm{P}$ adsorbed initially (native $\mathrm{P}$ ) and the higher the concentrations of native $P$ the smaller the size of the adsorption sites left over for $P$ added in the form of amendments. Therefore, up on additions of $P$ bearing amendments to soils having higher $\mathrm{P}_{\text {ox }}$ only smaller amounts of $\mathrm{P}$ tend to be adsorbed and the remaining $\mathrm{P}$ would be forced to soil solution and become available. According to the correlation result from incubated soils, enhanced amount of available $\mathrm{P}$ was manifested where there was higher $\mathrm{HCl}$ extractable $\mathrm{P}$ (Ca bound $\mathrm{P}$ ) as liming materials are applied. The strong rationale for strong positive association between $\mathrm{HCl}-\mathrm{P}$ and readily available $\mathrm{P}$ might be the occurrence of dissolution rather than precipitation in acidic soils.

Meanwhile, those readily available fractions of $\mathrm{P}\left(\mathrm{NH}_{4} \mathrm{Cl}-\mathrm{P}, \mathrm{NaHCO}_{3}-\mathrm{Pi}\right.$ and $\left.\mathrm{NaHCO}_{3}-\mathrm{Po}\right)$ in the studied soils had strong and negative association with oxalate extractable $\mathrm{Fe}\left(\mathrm{Fe}_{\mathrm{ox}}\right)$, oxalate extractable $\mathrm{Al}\left(\mathrm{Al}_{\mathrm{ox}}\right)$ and $\mathrm{PSC}$. The results pointed out that the availability of $\mathrm{P}$ was very low in soils dominated by higher concentrations of free oxyhydroxides of $\mathrm{Fe}$ and $\mathrm{Al}$. In addition, $\mathrm{NaOH}-\mathrm{Pi}$ and $\mathrm{NaOH}-\mathrm{Po}$ were strongly and negatively correlated with $\mathrm{Fe}_{\mathrm{ox}}, \mathrm{Al}_{\mathrm{ox}}$ and $\mathrm{PSC}$. This could be an indication for reduction in free metallic oxyhydroxides $\left(\mathrm{Al}_{\mathrm{ox}}, \mathrm{Fe}_{\mathrm{ox}}\right)$ and $\mathrm{PSC}$ with increasing amount of $\mathrm{P}$ added through inorganic $\mathrm{P}$ and vermicompost application as well as lime.

Table 6 Correlation matrix obtained from soil properties in SC1 sampling site

\begin{tabular}{|c|c|c|c|c|c|c|c|c|c|c|c|}
\hline & M-3 & $\mathrm{NH}_{4} \mathrm{Cl}-\mathrm{P}$ & $\begin{array}{l}\mathrm{NaHCO}_{3}^{-} \\
\mathrm{Pi}\end{array}$ & $\begin{array}{l}\mathrm{NaHCO}_{3}^{-} \\
\text {Po }\end{array}$ & $\mathrm{NaOH}-\mathrm{pi}$ & $\mathrm{NaOH}-\mathrm{po}$ & $\mathrm{HCl}-\mathrm{p}$ & $\mathrm{Al}_{\mathrm{ox}}$ & $\mathrm{Fe}_{\mathrm{ox}}$ & $P_{o x}$ & PSC \\
\hline $\mathrm{pH}$ & $0.19 *$ & $0.09 \mathrm{~ns}$ & $0.38^{\star \star}$ & $0.26 * \star$ & $0.07 n s$ & $0.13 \mathrm{~ns}$ & $0.75^{\star \star}$ & $-0.54^{\star \star}$ & -0.27 ** & $0.46^{\star \star}$ & $-0.48^{* *}$ \\
\hline M-3 & & $0.94 \star *$ & $0.91 * \star$ & $0.59 \star \star$ & $0.95^{\star \star}$ & $0.78^{\star \star}$ & $0.35^{\star \star}$ & -0.61 ** & -0.69 ** & $0.82^{\star \star}$ & $-0.73^{\star \star *}$ \\
\hline $\mathrm{NH}_{4} \mathrm{Cl}-\mathrm{P}$ & & & $0.91^{\star *}$ & $0.49 \star \star$ & 0.96 ** & $0.83^{\star \star}$ & $0.29 * \star$ & -0.54 ** & -0.61 ** & $0.79 \star \star$ & $-0.64^{\star *}$ \\
\hline $\begin{array}{l}\mathrm{NaHCO}_{3}^{-} \\
\mathrm{Pi}\end{array}$ & & & & $0.56 * \star$ & $0.88^{* *}$ & $0.77^{\star \star}$ & $0.53^{* *}$ & $-0.59 * *$ & -0.63 ** & $0.82^{\star \star}$ & -0.69 ** \\
\hline $\begin{array}{l}\mathrm{NaHCO}_{3}- \\
\text { Po }\end{array}$ & & & & & $0.64 * *$ & $0.73^{* *}$ & $0.44^{\star *}$ & $-0.35^{\star \star}$ & -0.59 ** & $0.66^{\star \star}$ & $-0.51^{\star \star}$ \\
\hline $\mathrm{NaOH}-\mathrm{pi}$ & & & & & & $0.85^{\star \star}$ & $0.27^{\star \star}$ & $-0.49 \star \star$ & $-0.63^{\star *}$ & $0.79 \star \star$ & $-0.62^{\star \star}$ \\
\hline $\mathrm{NaOH}-\mathrm{po}$ & & & & & & & $0.33^{* *}$ & $-0.37 \star \star$ & -0.60 ** & $0.77^{\star \star}$ & $-0.53^{\star *}$ \\
\hline $\mathrm{HCl}-\mathrm{p}$ & & & & & & & & $-0.39 \star \star$ & -0.39 ** & $0.66^{* *}$ & $-0.44^{\star *}$ \\
\hline $\mathrm{Al}_{\mathrm{ox}}$ & & & & & & & & & $0.56^{\star \star}$ & -0.60 ** & $0.92^{* *}$ \\
\hline $\mathrm{Fe}_{\mathrm{ox}}$ & & & & & & & & & & $-0.69 \star *$ & $0.84^{\star *}$ \\
\hline $\mathrm{P}_{\text {ox }}$ & & & & & & & & & & & $-0.72^{\star \star *}$ \\
\hline
\end{tabular}

\section{Conclusions}

It can be seen that unlike separate applications of inorganic P, both lime and vermicompost had significant effect in enhancing the pH of the studied soil. Combined application of lime, vermicompost and inorganic $\mathrm{P}$ is more effective in reducing exchangeable acidity, exchangeable aluminum compared to the single treatment. Even though, sole applications of lime, vermicompost and inorganic P had significant effects on Mehlich-III extractable available P; combined applications of these amendments had brought higher and better available P. Oxalate and dithionite citrate bicarbonate extractable Fe and Al, which indicate the potential adsorption capacity of soils, could be reduced significantly by combined use of the treatments over single applications. Despite having no significant effects on the distributions of $\mathrm{P}$ forms, sole application of lime with increasing rates reduced the magnitude of $\mathrm{NaOH}$ extractable $\mathrm{P}$ and enhanced the readily available $\mathrm{P}$ fractions $\left(\mathrm{NH}_{4} \mathrm{Cl}-\mathrm{P}, \mathrm{NaHCO}_{3}-\mathrm{Pi}\right.$ and $\left.\mathrm{NaHCO}_{3}-\mathrm{Po}\right)$.

Therefore, combined applications of lime, vermicompost and inorganic P to acidic soils of Goha- 1 in Cheha district could convey enhanced amount of available P. It can also ensure the maintenance of higher levels of labile P in the soil and highly significantly influenced those soil properties as well. Sole 
application of inorganic $\mathrm{P}$ and vermicompost increased the labile inorganic $\mathrm{P}$ fractions in the soil and decreased the potential sorption capacities of the soil. It can be concluded that integrated applications of these amendments could contribute towards meeting crop P requirements. Therefore, the smallholder farmers and stakeholders in the study area should implement technologies like low input P management strategy and application of lime, to alleviate phosphorous and acidity related problems.

\section{Abbreviations}

ANOVA

Analysis of variance

CCE

Calcium carbonate equivalents

CEC

Cation exchange capacity

CRD

Completely randomized design

DPS

Degree of $\mathrm{P}$ saturation

EIAR

Ethiopian institute of agricultural research

FAAS

Flame atomic absorption spectroscopy

FAO

Food and Agriculture Organization

PSC

Phosphorous adsorption capacity

OM

Organic matter

SAS

Statistical Analysis System

TSP

Triple super phosphate

VC

Vermicompost

\section{Declarations}

\section{Ethics approval and consent to participate}

Not applicable

\section{Consent for publication}

Not applicable

\section{Availability of Data and materials}

Not applicable

\section{Competing interest}

No conflict of interest

\section{Funding}

Swedish International Cooperation Development Agency (SIDA) and Madda Walabu University, only for sample collection and laboratory analysis.

\section{Authors' contributions}

Bereket Ayenew collected, analyzed, interpreted the data and made the final write up. Asmare Melese as a co-authors edited and approved the final manuscript

\section{Acknowledgments}

The project was funded by SIDA (Swedish International Development Cooperation Agency and Madda Walabu University. Thus we would like to thank these institutions. We would also thank the anonymous reviewers who contributed significantly to the improvement of the article. 


\section{Authors' information}

${ }^{1}$ Madda Walabu University, College of Natural and Computational Sciences, Department of Chemistry, Bale-Robe, Ethiopia; ${ }^{2}$ Debre Berhan University, College of Agriculture and Natural Resource Sciences, Department of Plant Science, Debre Berhan, Ethiopia

\section{References}

1. Abdala DB, da Silva IR, Vergütz L, Sparks DL (2015) Long-term manure application effects on phosphorus speciation, kinetics and distribution in highly weathered agricultural soils. Chemosphere. 119: 504-514.

2. Achalu C, Martti E, Kari Y (2014) Sequential Fractionation Patterns of Soil Phosphorus Collected from Different Land Use Systems of Dire Inchine District, West Shawa Zone, Ethiopia. Ethiopia. American-Eurasian Journal of Scientific Research. 9(3):51:57.

3. Achalu C, Heluf G, Kibebew K, Abi T (2012b) Response of barely to liming of acid soils collected from different land use systems on Western Oromia, Ethiopia. Journal of Biodiversity and Environmental Sciences. 2: 1-13.

4. Achieng JO, Ouma G, Odhiambo G, Muyekho F (2010) Effect of farmyard manure and inorganic fertilizers on maize production on Alfisols and Ultisols in Kakamega, western Kenya. Agriculture and Biology Journal of North America. Agric. Biol. J. N. Am. 1(4): 430-439.

5. Adnan A, Mavinic DS, Koch FA (2003) "Pilot-scale study of phosphorus recovery through struvite crystallization-examining to process feasibility." Journal of Environmental Engineering and Science. 2(5):315-324.

6. Ahmed MF, Kennedy IR, Choudhury ATMA, Kecskes ML, Deaker R (2008) Phosphorous adsorption in some Australine soils and influence of bacteria on the desorption of phosphorous, Communication in soil science and Plant Analysis. 39: 1269-1294.

7. Andrade FV, Mendonça ES, Alvarez VVH, Novais RF (2003) Adição de ácidos orgânicos e húmicos em Latossolos e adsorção de fosfato. R Bras Ci Solo. 27:1003-11.

8. Ashoka S, Abul MdK, Khan OT, Imam H, Farzana A (2014) Evaluation of Available Phosphorus by Soil Test Methods in an Acidic Soil Incubated with Different Levels of Lime and Phosphorus. Open Journal of Soil Science. 4:103-108. Sci Res.

http://www.scirp.org/journal/ojsshttp://dx.doi.org/10.4236/ojss.2014.43014

9. Asmare M, Heluf G, Markku YH, Birru Y (2015) Phosphorus Status, Inorganic Phosphorus Forms, and Other Physicochemical Properties of Acid Soils of Farta District, Northwestern Highlands of Ethiopia. Hindawi Publishing CorporationApplied and Environmental Soil Science. Volume, Article ID 748390,11 pages http://dx.doi.org/10.1155/2015/748390.

10. Ayenew B, Abi T, Kibebew K, Asmare M (2018a) Chemical forms of phosphorous and physicochemical properties of acid soils of Cheha and Dinsho districts, southern highlands of Ethiopia. Environ Syst Res. 7:15 https://doi.org/10.1186/s40068-018-0118-9.

11. Ayenew B, Abi T, Kibebew K, Asmare M (2018b) Phosphorous status and adsorption cgaracteristics of acid soils from Cheha and Dinsho districts, southern highlands of Ethiopia. Environ Syst Res.7:17https://doi.org/10.1186/s40068-018-0121-1.

12. Barrow NJ, Bolland MDA, Allen DG (1998) Effect of addition of superphosphate on sorption of phosphate. Austr. J. Soil Res.36:359-372.

13. Berhane F, Sahlemedhin S (2003) Assessment of the different phosphorus forms in some agricultural soils of Ethiopia. Ethiopian Journal of Natural Resources. 5:193-213.

14. Börling K, Otabbong E, Barberis E (2001) Phosphorus sorption in relation to soil properties in some cultivated Swedish soils. Nutrient Cycling in Agroecosystems. 59:39-46.

15. Buni A (2015) Effects of liming acidic soils on improving soil properties and yield of haricoat bean. Buni J. Biorem. Biodeg.6(2):1-3.

16. Celi L, Barberis E, Marsan FA (2000) Sorption of phosphate on goethite at high concentration. Soil Sci.165:657-664.

17. Chandrasekaran B, Annadurai K Somasundaram E (2010) A Text Book of Agronomy, New Age of International Publishers.

18. Chen GC, He ZL, Huang CY (2000) Microbial biomass phosphorus and its significance in predicting phosphorus availability in red soils. Commun Soil Sci Plant Anal. 31:655-667.

19. Ch'ng HY, Osumanu HA, A/Majid NM (2014) Improving Phosphorus Availability in an Acid Soil Using Organic Amendments Produced from Agroindustrial Wastes. The scientific world journal. http://dx.doi.org/10.1155/2014/506356

20. Cui Y, Xiao R, Xie Y, Zhang M (2017) Phosphorus fraction and phosphate sorption-release characteristics of the wetland sediments in the Yellow River Delta. Physics and Chemistry of the Earth. 1-9, http://dx.doi.org/10.1016/j.pce.2017.06.005.

21. Dai KJ, He F, Guan HL, Shen YX, Zhang GM (2006) Research advances in plant and its low-phosphorus environment e inducement, adaptation and counter measures. Chinese Journal of Ecology. 25 (12): 1580-1585

22. Dawit S, Lehmann J, Tekalign M, Fritzsche F, Wolfgang Z (2002) Phosphorus forms and dynamics as influenced by land use changes in the sub-humid Ethiopian highlands. Geoderma. 105:21-48.

23. EIAR (Ethiopian Institute of Agricultural Research) (2011. Coordination of national agricultural research system, Ethiopia. English and Amharic Version. EIAR, Addis Ababa, Ethiopia.

24. Elias M, Gichangi, Pearson NS, Mnkeni \& Philip C, Brookes (2010) Goat manure application improves phosphate fertilizer effectiveness through enhanced biological cycling of phosphorus, Soil Science and Plant Nutrition, 56:6, 853-860. DOI: 10.1111/j.1747-0765.2010.00515.x

25. Erich MS, Fitzgerald CB, Porter GA (2002) The effect of amendments on phosphorus chemistry in a potato cropping system. Agriculture, Ecosystems andEnvironment. 88:79-88.

26. Fageria NK (2009) The Use of Nutrients in CropPlants. CRC Press, Taylor and Francis Group, USA 
27. FAO (Food and Agriculture Organization) (1988) Provisional soil map of ethiopia. Land use planning project. Addis Ababa, Ethiopia.

28. Gavlak RG, Horneck DA, Miller RO (2005) Soil, plant and water reference methods for the western region. WREP $125,3^{\text {rd }}$ edition

29. Gikonyo EW, Zaharah AR, Hanafi MM Anuar AR (2011) Degree of Phosphorus Saturation and Soil Phosphorus Thresholds in an Ultisol Amended with Triple Superphosphate and Phosphate Rocks. The Scientific World JOURNAL. 11:1421-1441

30. Goldberg S, Scalera E, Adamo P (2008) Molybdenum adsorption by volcanic Italian soils. Communication in Soil Science and Plant Analysis. $39: 693-706$.

31. Gopinath KA, Mina BL (2011) "Effect of organic manures on agronomic and economic performance of garden pea (Pisumsativum) and on soil properties." Indian Journal of AgriculturalSciences. 81(3):236-239.

32. Gopinath KA, Saha S, Mina BL (2011) "Effects of organic amendments on productivity and profitability of bell pepper french bean-garden pea system and on soil properties during transition to organic production." Communications in SoilScience and Plant Analysis. 42(21):2572-2585.

33. Gunatilaka A (1988) Estimation of the available P-pool in a large fresh water marsh. Arch. Hydrobiol. Beih. Ergebin. Limnol. 30:15-24.

34. Guppy CN, Menzies NW, Moody PW, Blamey FPC (2005) Competitive sorption reaction between phosphorus and organic matter: a review. Aust J Soil Res. 43:189-202.

35. Hartono A, Vlek PLG, Moawad A, Rachim A (2000) Changes in phosphorus fractions on an acidic soil induced by phosphorus fertilizer, organic matter and lime. J.II.Tan.Lingk. 3(2): 1-7.

36. Haynes R, Mokolobate M (2001) Amelioration of Al toxicity and P deficiency in acid soils by addition of organic residues: A critical review of the phenomenon and the mechanisms involved. Nut. Cyc. Agro. 59:47-63.

37. Hedley MJ, Stewart JWB, Chauhan BS (1982) Changes in inorganic and organic soil phosphorus fractions induced by cultivation practices and by laboratory incubations. Soil Sci. Soc. Am. J. 46: 970-976.

38. Hirpa L, Dechassa N, Gebeyehu S, Bultosa G, Mekbib F (2013) Response to Soil Acidity of Common Bean Genotypes (Phaseolus vulgaris L.) Under Field Conditions at Nedjo, Western Ethiopia. Science, Technology and Arts Research Journal. 2(3): 3 - 15.

39. Hooda PS, Rendell AR, Edwards AC, Withers PJA, Aitken MN, Trusedale VW (2000) Relating soil phosphorus indices to potential phosphorus release to water. J. Environ. Qual. 29:1166-1171.

40. Hue NV, Ikawa H, Silva JA (1994) Increasing plant-available phosphorus in an Ultisol with a yard-waste compost. Commun Soil Sci Plant Anal. 25: 32913303.

41. Ilker U, Ismail ET (2014) Short-Term Effect of Vermicompost Application on Biological Properties of an Alkaline Soil with High Lime Content from Mediterranean Region of Turkey. Hindawi Publishing Corporation the Scientific WorldJournal. Volume 2014, Article ID 395282,11 pages http://dx.doi.org/10.1155/2014/395282

42. lyamuremye F, Dick RP (1996) Organic amendments and phosphorus sorption by soils. Advances in Agronomy. 56: $139-185$.

43. Iyamuremye F, Dick RP, Baham J (1996) Organic amendments and phosphorus dynamics: Il distribution of soil phosphorus fractions. Soil Sci. 161:436443.

44. Janardhanan L, Daroup SH (2010) Phosphorous sorption in organic acids in south Florida, Soil Science Society of America journal. 74:1597-1606.

45. Kamprath EJ (1984) Crop Response to Lime in the Tropics. In: Adams, F., Ed., Soil Acidity and Liming, 2nd Edition, Agronomy Monograph 12, Agronomy and Soil Science Society of America, Madison. 349-368.

46. Kang JH, Hesterberg D, Osmond DL (2009) Soil organic matter effects on phosphorus Sorption: a path analysis. Soil Sci. Soc. Am. J. 73:360-366.

47. Lan ZM, Lin XJ, Wang F, Zhang H, Chen CR (2012) Phosphorus availability and rice grain yield in a paddy soil in response to long-term fertilization. Biol. Fertil. Soils. 48: 579-588.

48. Li YY, Yang R, Gao R, Wei HA, Chen AL and Li Y (2015) Effects of long-term phosphorus fertilization and straw incorporation on phosphorus fractions in subtropical paddy soil. J. Integr. Agric. 14:365-373.

49. Lordan J, Pascual M, Fonseca F (2013) Use of rice husk to enhance peach tree performance in soil switch limiting physical properties. Soil Tillage and Research. 129: 19-22.

50. Magdoff FR (1999) Comparison of phosphorus soil test extractants for plant availability and environmental assessment. Soil Science Society of America Journal. 63: 999-1006.

51. McKeague JA, Day JH (1966) Dithionite and oxalate extractable Fe and Al as acids in differentiating various classes of soils. Canadian Journal of Soil Science. 46:13-22.

52. Mehra OP, Jackson, ML (1960) Iron oxide removal from soils and clays by a dthionite-citrate system buffered with sodium bicarbonate. Clays and Clay Minerals. 7:317-327.

53. Mesfin A (2007) Nature and Management of Acid Soils in Ethiopia. Addis Ababa, Ethiopia.

54. Negassa W, Leinwebe P (2009) How does the Hedley sequential phosphorus fractionation reflect impacts of land use and management on soil phosphorus: A review J. Plant Nutr. Soil Sci. 172: 305-325 DOI: 10.1002/jpln.200800223 305.

55. Oluwatoyinbo Fl, Akande MO, Makinde EA, Adediran JA (2009) Growth and Yield Response of Okra to Lime and Compost on an Acid Soil in the Humid Tropics. Research Journal of Agriculture and Biological Sciences. 5(5): 858-863.

56. Pavan MA, Androcioli FA (1995) Fracionamento de fosforo em un experiment0 de manejo da fertilidade do solo para producao de cafe no noroeste de Parana. Arquivos de Biologia e Tecnologia. 38:157-165.

57. Rayment GE, Lyons DJ (2011) 'Method 4b1 pH of 1:5 soil 0.01M Calcium chloride extract-direct (without stirring during measurement)', 'Method13A1 Oxalate extractable iron, aluminium and silicon'. Method 9B1 bicarbonate extractable P (Colwell P) - manual colour' "method 9J1 phosphate sorption 
curve - manual colour' in soil chemical methods-Australasia,CSIRO, Publishing, Australia

58. Reddy K, Wang Y, DeBusk W, Fisher M, Newman S (1998) Forms of soil phosphorus in selected hydrologic units of the Florida Everglades. Soil Sci. Soc. Am. J. 62:1134-1147.

59. Reshid A (2016) Evaluation of Vermicompost on Maize Productivity and Determine Optimum Rate for Maize Production. World Journal of Biology and Medical Sciences. 3(1):9-22.

60. Ritchie GSP (1994) "Role of dissolution and precipitation of minerals in controlling soluble aluminumin acidic soils" Advancesin Agronomy. 53:47-83.

61. Roderigo J, Aberto VI, Tales T, Vidal B (2016) Iron oxides and organic matter on soil phosphorous availability. Ciencia e Agrotecnologia. 40(4):369-379.

62. SAS (Statistical Analysis System) version 9.1. SAS Institute (2004) SAS/STAT user's guide. Proprietary software version 9.00. SAS Institute, Inc., Cary, NC.

63. Sharpley AN, McDowell RW, Kleinnman JA (2004) Amounts, forms, and solubility of phosphorus in soils receiving manure. Soil Sci Soc Am J. 68:20482057.

64. Shiferaw B (2004) Soil phosphorous fractions influenced by different cropping system in andosols and nitisols in Kambata-Tenbaro and Wolaita Zones, SNNPRS, Ethiopia [M.S. thesis], Alemaya University, Dire Dawa, Ethiopia.

65. Sims JT, Pierzynski GM (2005) chemistry of phosphorous in soils" I chemical processes in soils, Dick, W.A, Tabatabai, M.A, and Sparks, D.L eds., Soil Science Society of America inc., Wisconsin, USA

66. Smithson P (1999) "Special issue on phosphorus availability, uptake and cycling in tropical agroforestry," Agroforestry Forum. 9(4):37-40.

67. Tan KH (2000) Environmental Soil Science, $2^{\text {nd }}$ ed., Marcel Dekker Inc., New York, USA

68. Teshome Y, Heluf G, Kibebew K, Sheleme B (2013) Impacts of Land Use on Selected Physicochemical Properties of Soils of Abobo Area, Western Ethiopia. Agriculture, Forestry and Fisheries. 2(5): 177-183. doi:10.11648/j.aff.20130205.11.

69. Tiessen H, Stewart JWB, Cole CV (1984) Pathways of P transformations in soils of differing pedogenesis. Soil Sci. Soc. Amer. J. 48:853-858.

70. Torrent J, Barron V, Schwertmann U (1990) Phosphate adsorption and desorption by Geothites Differing in crystal morphology. Soil Science Society of American Journal. 54:1007-1012.

71. Vaananen R, Hristov J, Tanskanen N, Hartikainen H, Nieminen M, Ilvesniemi H (2008) Phosphorous sorption protperties in podzolic forest soils and soil solution phosphorous concentration in undisturbed and disturbed soil profiles, Boreal Environment Research, 13:553-567

72. Van der Zee SEATM, Nederlof M.M, Van Riemsdijk WH, de Haan FAM (1988) Spatial variability of phosphate adsorption parameters. Journal of Environmental Quality. 17:682-688.

73. Van Straaten P (2007) Agro geology: the use of rocks for crops.Enviroquest Ltt, 352 River Toad, Cambridge, Ontario N3C 2B\& Canada.

74. Vincent AG, Turner BL, Tanner EVJ (2010) Soil organic phosphorus dynamics following perturbation of litter cycling in a tropical moist forest. Eur J Soil Sci. 61:48-57.

75. Wakene N, Heluf Gebrekidan (2003) Forms of phosphorus and status of available micronutrients under different land use systems of Alfisols in Bako area of Ethiopia. Ethiopian Journal of Natural Resource. 5(1):17-37.

76. Walker TW, Syers JK (1976) The fate of phosphorus during pedogenesis. Geoderma. 15:1-19.

77. Walkley A, Black IA (1934) An examination of the Degtjareff method for determining soil organic matter and a proposed modification of the chromic acid titration method. Soil Sci. 37:29-38.

78. Wassie H, Shiferaw B (2009) Mitigation of Soil Acidity and Fertility Decline Challenges for Sustainable Livelihood Improvement: Research Findings from Southern Region of Ethiopia and its Policy Implications. Awassa Agricultural Research Institute.

79. Whalen JK, Chang C, Clayton W, Care foot, P. 2000. Cattle manure amendments can increase the pH of acid soils. Soil Science Society of America Journal. 64:962-966.

80. Wolf AM, Baker DE (2008) Colorimetric method for P measurement in ammonium oxalate soil extracts. Communication in soil science and Plant analysis. 21:2257- 2263.

81. Yan X, Wang D, Zhang H, Zhang G, Wei Z (2013) Organic amendments affect phosphorus sorption characteristics in a paddy soil. Agric. Ecosyst. Environ. 175:47-53.

82. Yan X, Zongqiang W, Qianqian H, Zhihong L, Jianfu W (2017) Phosphorus fractions and sorption characteristics in a subtropical paddy soil as influenced by fertilizer sources. Geoderma.295:80-85.

83. Zhang Q, Wang GH, Feng YK, Sun QZ, Witt C, Dobermann A (2006) Changes in soil phosphorus fractions in a calcareous paddy soil under intensive rice cropping. Plant Soil. 288:141-154. 